\title{
PENGARUH KUALITAS PELAYANAN DAN KUALITAS PRODUK TERHADAP KEPUASAN KONSUMEN (KFCARJUNA MEDAN PERJUANGAN)
}

\author{
Ivo Selvia Agusti ${ }^{1)^{*}}$ Yogaswara Verano ${ }^{1)}$ \\ ${ }^{1)}$ Fakultas Ekonomi Universitas Negeri Medan \\ *Penulis Korespondensi: unimedivo@yahoo.co.id ${ }^{1)}$ yogaswara3232@gmail.com ${ }^{1)}$
}

\begin{abstract}
ABSTRAK
Penelitian ini bertujuan untuk mengetahui seberapa besar pengaruh kualitas pelayanan (X1) kualitas produk (X2) Terhadap Kepuasan konsumen (Y) di KFC Medan Perjuangan Model penelitian yang digunakan yakni dengan metode kuantitatif, asosiatif dengan populasi dalam penelitian ini adalah pelanggan yang KFC Medan Metode penarikan sampel menggunakan rondom sampling didapat sebanyak 44 responden yang berkunjung pada waktu penelitian dilakukan.Instrumen angket penelitian menggunakan data primer dan skunder. Menggunakan SPSS. Metode analisis dalam pengolahan data adalah uji validitas dan reliabilitas, uji regresi linear sederhana, koefisien determinasi, uji hipotesis (uji-t), dan uji korelasi pearson product moment. Hasil penelitian menunjukkan bahwa Kualitas Pelayanan (X1), Kualitas Makanan (X2), berpengaruh signifikan juga terhadap Kepuasan Pelanggan (Y). Oleh karena itu, penting untuk mempertahankan variabel-variabel tersebut pada standar kualitas karena memiliki dampak signifikan terhadap kepuasan pelanggan
\end{abstract}

Keywords: Kualitas pelayanan, kualitas makanan, kepuasan pelanggan, restoran cepat saji.

Article Information:

Received Date: 2 Februari 2022

Revised Date: 10 Februari 2022

Accepted Date: 21 Februari 2022 


\section{PENDAHULUAN}

Salah satu gaya hidup yang berkembang saat ini adalah mengkonsumsi makanan yang ditawarkan oleh restoran cepat saji. Makanan cepat saji menjadi pilihan utama bagi masyarakat perkotaan terutama bagi masyarakat yang memiliki rutinitas dan kesibukan setiap harinya. Hal tersebut berdampak pada timbulnya kebutuhan masyarakat terhadap makanan yang cepat dan instant. Hal ini bisa kita lihat dengan ramainya pengunjung restoran cepat saji setiap harinya. Kehadiran fast food sangat disukai oleh masyarakat perkotaan karena cara penyajiannya yang cepat sehingga memudahkan untuk menyantapnya dimana saja.

Seorang pelanggan yang puas akan menjadi aset yang sangat berharga bagi perusahaan. Kepuasan pelanggan juga merupakan salah satu kunci untuk menciptakan loyalitas pelanggan, karena pelanggan yang puas akan cenderung loyal. Kepuasan akan muncul jika pelanggan menilai positif pengalaman transaksinya. Manajemen hubungan pelanggan yang baik menciptakan kepuasan pelanggan. Hasilnya, pelanggan yang puas tetap setia dan menceritakan hal-hal yang baik tentang perusahaan dan produknya kepada orang lain (Kotler, 2009).

Kepuasan dapat dipengaruhi oleh perbandingan konsumen atas kualitas pelayanan dan kualitas produk yang diberikan dengan yang diharapkan oleh para pelanggan. Beberapa pelanggan layak untuk menerima perhatian dan pelayanan yang lebih dibandingkan dengan pelanggan lainnya. Ada pelanggan yang tidak akan pernah memberikan umpan balik, tidak peduli berapa banyak perhatian yang akan diberikan pihak perusahaan yang akan diberikan kepadanya, dan tidak peduli seberapa puas mereka, dengan demikian antusiasme tentang kepuasan pelanggan harus dilakukan dengan analisaanalisa dari perusahaan.

Kualitas produk merupakan keseluruhan gabungan karakteristik produk dari pemasaran, rekayasa, pembikinan dan pemeliharaan yang membuat produk yang digunakan memenuhi harapan harapan pelanggan. Jadi kualitas produk adalah sejumlah atribut atau sifat-sifat yang dideskripkan di dalam produk (barang dan jasa) dan digunakanuntuk memenuhi harapan-

Kualitas layanan merupakan upaya perusahaan untuk memenuhi harapan pelanggan melalui jasa yang mengiringi produk yang ditawarkan dengan tujuan untuk menciptakan kepuasan pelanggan. Menurut Tjiptono dan Chandra (2011), bahwa kualitas layanan yaitu ukuran seberapa baik tingkat pelayanan yang diberikan, serta sesuai dengan ekspektasi pelanggan.

Makanan cepat saji atau Fast Food merupakan hidangan alternatif yang biasanya berupa ayam goreng, kentang goreng, burger, pasta, atau roti isi. Restoran cepat saji merupakan salah satu perusahaan yang bergerak dibidang penyediaan makanan, minuman dan penyediaan layanan lainnya. Salah satu restoran cepat saji yang banyak diminati oleh masyarakat perkotaan adalah Kentucky Fried Chicken (KFC)). Kentucky Fried Chicken (KFC) adalah salah satu perusahaan cepat saji yang menyediakan ayam goreng cepat saji terbaik saat ini Kualitas yang rendah akan menimbulkan ketidakpuasan pada pelanggan, tidak hanya pelanggan yang menikmati hidangan di restoran tersebut tapi juga berdampak pada orang lain. Pelanggan yang kecewa akan bercerita paling sedikit kepada 15 orang lainnya (Lupiyoadi dan Hamdani 2016). Untuk itu, upaya perbaikan kualitas layanan maupun kualitas produk akan jauh lebih efektif bagi keberlangsungan bisnis Woro \& Naili (2013) dan Qomariah (2012) mengemukakan secara umum ketertarikan konsumen terhadap suatu produk dan jasa adalah kualitas. Maka tidak heran jika banyak perusahaan memperbaiki kualitas pelayanan mereka guna menarik konsumen yang rela membelanjakan banyak uang untuk mendapatkan kualitas, namun demikian faktor lain tetap dibangun seperti promosi, strategi harga, lokasi dan lain sebagainya. Berdasarkan hal tersebut maka peneliti ingin melakukan penelitian yang berjudul Pengaruh Kualitas Pelayanan dan Kualitas Produk Terhadap Kepuasan Konsumen Pada Makanan Siap Saji KFC Medan Perjuangan.

\section{TINJAUAN PUSTAKA}

\section{KUALITAS PELAYANAN}

Tjipto dan Chandra (2011)

mendefinisikan kualitas pelayanan sebagai 
bentuk upaya dalam mewujudkan kebutuhan, keinginan pembeli, serta ketepatan penyampaian produk tersebut agar dapat mengimbangi harapan pembeli. Terdapat 5 Indikator untuk kualitas pelayanan, yaitu: 1) Bukti fisik (tangible), merupakan bukti langsung yang dapat secara langsung dinilai melalui visual atau tampilan dari fasilitas fisik. Seperti : keamanan parkir saat berbelanja, penampilan karyawan menarik, desain gedung yang unik dan menarik. 2) Keandalan (reliability), merupakan dimensi kesamaan atau sesuai tidaknya pelayanan yang diberikan terhadap apa yang dijanjikan kepada

Pengaruh Kualitas Pelayanan Terhadap Kepuasan Konsumen Menurut Familiar dan Maftukhah (2015) menyatakan bahwa kualitas pelayanan yang ideal adalah ketika pelayanan yang diterima melampaui harapan konsumen dan sebaliknya apabila pelayanan yang diterima lebih rendah dari yang diharapkan maka kualitas pelayanan dianggap buruk. Tjiptono, Fandy. (2012) juga Menyatakan kualitas pelayanan adalah tingkat keunggulan yang yang diharapkan dan pengenndalian atas tingkat keunggulan untuk memenuhi keinginan konsumen. Rahmadani, Suardana, dan samudra. Kualitas pelayanan mempunyai efek secara langsung terhadap kepuasan konsumen. Penelitian Sebelumnya Menurut Krisdianti (2019) Kualitas pelayanan mempunyai pengaruh yang signifikan secara serentak terhadap kepuasan konsumen. Menurut Fauzi dan Mandala (2019). Menurut Santoso (2019) Kualitas layanan berpengaruh positif dan signifikan terhadap kepuasan pelanggan. Kualitas pelayanan memiliki pengaruh terhadap kepuasan konsumen

Pengaruh Kualitas Produk Terhadap Kepuasan Konsumen Menurut Assauri (2015) Kualitas produk adalah pernyataan tingkat kemampuan dari suatu merk atau produk tertentu dalam melaksanakan fungsi yang diharapkan dan sebagai bahan untuk memenuhi kebutuhan dasar manusia. Sedangkan menurtut Weenas (2013), Kualitas produk merupakan salah satu hal yang dapat mempengaruhi kepuasan konsumen. Penelitian sebelumya Menurut Setyo (2017) Kualitas produk berpengaruh secara signifikan terhadap kepuasan konsumen. Hal ini sesuai dengan penelitian terdahulu yang sudah dilakukan. Menurut Fauzi dan Mandala (2019) Kualitas produk berpengaruh positif dan signifikan terhadap kepuasan pelanggan. Menurut Thawil (2019). Kualitas produk telah membuktikan hubungan dan signifikan variasi dari kepuasan konsumen. Sedangkan menurut Hartanto A (2019). Kualitas produk tidak memiliki pengaruh yang signifikan terhadap kepuasan konsumen pelanggan baik dengan pemberian informasi yang sesuai hingga bentuk pelayanan yang handal dan tepat waktu (onetime). Seperti : ketelitian kasir melayani pelanggan, daya tanggap/respon karyawan membantu pelanggan berbelanja dan dan kemampuan karyawan menguasai penempatan produk. 3) Daya tanggap (responsiveness), merupakan bentuk kesediaan karyawan dalammemberikan pelayanan kepada konsumen. Seperti : kecepatan karyawan menangani masalah pelanggan, kemauan karyawan memberikan perhatian secara individu, dan ketanggapan informasi yang jelas kepada pelanggan. 4) Jaminan (assurance), merupakan dimensi yang dapat memberikan jaminan atau rasa aman kepada konsumen sehingga akan menumbuhkan rasa percaya terhadap perusahaan. Seperti : kemudahan berkomunikasi antar karyawan dengan para pelanggan dan pemberian informasi yang jelas kepada pelanggan 5) Empati (emphaty), merupakan dimensi kesediaan perusahaan untuk memperhatikan kebutuhan konsumen dan kesediaan dalam memberi kemudan atau bantuan ketika konsumen mengalami permasalahan baik sebelum maupun setelah mengkonsumsi produk yang ditawarkan perusahaan. Seperti kemampuan berkomunikasi dengan pelanggan dan kemudahan dalam mendapat informasi produk.

\section{KUALITAS PRODUK}

Kotler dan Keller (2009) menjelaskan bahwa kualitas produk adalah suatu kondisi dinamis dari produk atau barang yang mempunyai manfaat bagi konsumen sesuai dengan kebutuhan dan harapan komsumen. Terdapat 3 indikator yang mempengaruhi kualitas produk, yaitu: 1) Spesifikasi Produk, adalah kriteria dari barang/jasa yang dapat memenuhi kebutuhan pengguna barang/jasa yang ketika dimanfaatkan memiliki nilai tambah. 2) Kinerja Produk, adalah suatu nilai, fungsi atau hasil yang diperoleh dari suatu barang atau jasa. Konsumen akan membeli suatu barang atau jasa akan melihat nilai dan fungsi yang akan mereka dapatkan dari produk 
tersebut. 3) Tampilan Produk, merupakan kriteria fisik dari suatu produk seperti warna produk, porsi, bentuk, tekstur, aroma, rasa, dan tingkat kematangan

\section{KEPUASAN KONSUMEN}

Tjiptono Chandra (2011) mengutip dari Mowen bahwa kepuasan konsumen dirumuskan sebagai bentuk sikap atau perilak u konsumen terhadap suatu barang atau jasa yang telah dikonsumsi atau diperoleh, sehingga akan menimbulkan rencana untuk pembelian ulang serta menimbulkan rasa kepuasan atau ketidakpuasan. Terdapat 5 indikator untuk Kepuasan konsumen, yaitu: 1) Kepuasan Pelanggan Keseluruhan, yaitu melalui kinerja produk secara umum 2) Dimensi Kepuasan Pelanggan, yaitu sebuah dimensi untuk mengukur kualitas pelayanan. Dengan menggunakan dimensi ini anda dapat mengetahui jarak antara ekspektasi pelanggan dengan harapan pelanggan terhadap layanan yang mereka terima. Konfirmasi Harapan, yaitu pengukuran kepuasan secara tidak langsung yang dilakukan dengan menyimpulkan kesesuaian atau ketidakpuasan antara harapan pelanggan dengan kinerja aktual suatu produk. 4) Niat Beli Ulang, yaitu kepuasan yang diukur berdasarkan kesediaan/kemauan pelanggan untuk melakukan pembelian kembali atas pelayanan sama yang telah dikonsumsi sebelumnya. 5) Kesediaan Untuk Merekomendasikan, yaitu kepuasan yang diukur ketika pelanggan melakukan marketing secara tidak langsung kepada seseorang atau sekelompok orang untuk melakukan pembelian terhadap produk yang ia gunakan/konsumsi.

Berdasarkan paparan diatas, maka hipotesis penelitian adalah:

$\mathrm{H} 1$ : terdapat pengaruh yang positif dan signifikan antara kualitas pelayanan (X1) terhadap kepuasan konsumen (Y)

$\mathrm{H} 2$ : terdapat pengaruh positif yang signifikan antara kualitas produk (X2) terhadap kepuasan konsumen (Y

\section{METODE PENELITIAN}

Penelitian ini dilakukan pada KFC ARJUNA, Jalan Perjuangan, Sei Kera Hilir I, Medan Perjuangan, Sumatera Utara, pada tanggal 18 April 2021, Populasi Konsumen dalam penelitian ini tidak terhingga sehingga peneliti menggunakan teknik pengambilan rondom sampling terhadap konsumen yang berkunjung dengan demikian jumlah sample 44 orang terdiri dari Wanita 31 orang, Pria 13 Orang, dengan umur 19-24 tahun. Sifat penelitian ini merupakan penelitian diskriptif kuantitatif. Maksudnya yaitu yaitu penelitian tentang data yang dikumpulkan dan dinyatakan dalam bentuk angka-angka, meskipun juga berupa data kualitatif sebagai pendukungnya, seperti kata-kata atau kalimat yang tersusun dalam angket, kalimat hasil konsultasi atau wawancara antara peneliti dan informan. Dalam menganalisis data digunakan uji asumsi klasik, analisis regresi linier berganda, uji t dan uji F, Koefisien Determinasi

\section{HASIL DAN PEMBAHASAN Uji Regresi Linier Berganda}

Berdasarkan hasil analisis tersebut diperoleh model regresi linier berganda sebagai berikut:

$$
\begin{aligned}
& \mathrm{Y}=0,305+0,229 \mathrm{X} 1+0,742 \mathrm{X} 2 \\
& \text { Keterangan : } \\
& \mathrm{X} 1=\text { Kualitas Pelayanan } \\
& \mathrm{X} 2=\text { Kualitas Produk } \\
& \mathrm{Y}=\text { Kepuasan Konsumen }
\end{aligned}
$$

Uji Hipotesis

Tabel 1 Uji Parsial (Uji T)

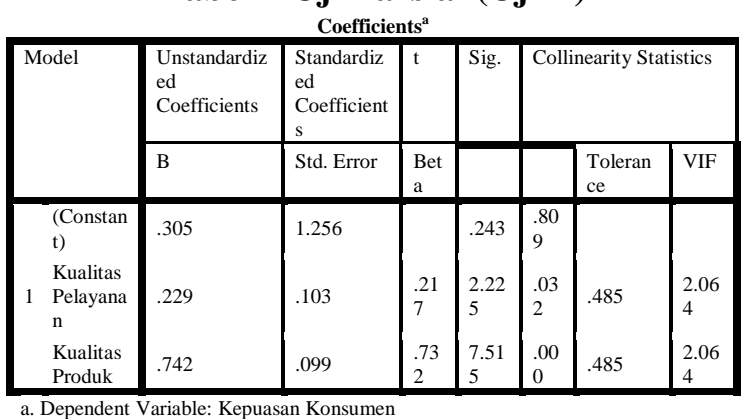

Berdasarkan hasil di atas diketahui bahwa nilai sig kualitas pelayanan adalah $0,032<0.05$, maka dapat disimpulkan bahwa hipotesis (H1) yang berbunyi "terdapat pengaruh yang positif dan signifikan antara kualitas pelayanan (X1) terhadap kepuasan konsumen (Y)", diterima

Kemudian, diketahui nilai sig 0,000< 0,05, maka dapat disimpulkan bahwa hipotesis $(\mathrm{H} 2)$ yang berbunyi "terdapat pengaruh positif yang signifikan antara kualitas produk (X2) terhadap kepuasan konsumen (Y)", diterima. 
Tabel 2 Uji Parsial (Uji F)

ANOVA $^{\mathrm{a}}$

\begin{tabular}{|c|c|c|c|}
\hline Sum of Squares & Df & Mean Square & $\mathrm{F}$ \\
\hline $\begin{array}{l}226.946 \\
52.781 \\
279.727\end{array}$ & \begin{tabular}{|l|}
2 \\
41 \\
43 \\
\end{tabular} & $\begin{array}{l}113.473 \\
1.287\end{array}$ & 88.145 \\
\hline
\end{tabular}

Berdasarkan ouput di atas diketahui nilai signifikansi untuk pengaruh X1 dan X2 secara simultan terhadap $\mathrm{Y}$ adalah sebesar $0,000<$ 0,05 , sehingga dapat disimpulkan bahwa hipotesis (H3) yang berbunyi "terdapat pengaruh kualitas pelayanan (X1) dan kualitas produk (X2) secara simultan terhadap terhadap kepuasan konsumen (Y)" diterima.

Tabel 3 Uji Koefisien Determinasi Model Summary

\begin{tabular}{|l|l|l|l|l|}
\hline $\begin{array}{l}\text { Mod } \\
\mathrm{el}\end{array}$ & $\mathrm{R}$ & R Square & Adjusted R Square & Std. Error of the Estimate \\
\hline 1 & $.901^{\mathrm{a}}$ & .811 & .802 & 1.135 \\
\hline
\end{tabular}

Uji determinasi ( $\mathrm{R}^{2}$ ) dilakukan untuk mengetahui besarnya sumbangan atau kontribusi antara variabel bebas kualitas pelayanan (X1) dan kualitas produk (X2) secara bersama-sama terhadapat variabel terikat kepuasan konsumen (Y).

Berdasarkan tabel di atas, diperoleh nilai $\mathrm{R}$ Square sebesar 0,811 atau $81,1 \%$ dimana hal ini menunjukkan bahwa besarnya sumbangan pengaruh yang diberikan oleh variabel kualitas pelayanan dan kualitas produk terhadap kepuasan dan loyalitas konsumen adalah sebesar $81,1 \%$, sedangkan sisanya sebesar $18,9 \%$ dipengaruhi oleh faktor-faktor lain yang tidak dibahas dalam penelitian ini Sejalan dengan penelitian Zahra (2021) bahwasannya sumbangan pengaruh yang diberikan oleh variabel kualitas pelayanan dan kualitas produk terhadap kepuasan dan loyalitas konsumen adalah sebesar 0,714 sebesar $71,4 \%$. Sedangkan sisanya $28,6 \%$ dipengaruhi oleh variabel lain di luar persamaan regresi ini atau variabel yang tidak diteliti.

\section{KESIMPULAN DAN SARAN}

Karakteristik konsumen KFC mayoritas berjenis kelamin perempuan. Konsumen yang datang terbanyak pada usia 16-25 tahun dan sebagian besar berpendidikan terakhir SMA serta berprofesi kebanyakan sebagai pelajar/mahasiswa. Tingkat pendapatan konsumen per bulan >Rp 1000000 dan setiap kali berkunjung, pelanggan KFC rata-rata menghabiskan Rp 20 000-RP 50000.

Berdasarkan hasil analis regresi berganda yang telah dikemukakan menunjukkan bahwa variabel kualitas pelayanan berbanding lurus atau positif terhadap tingkat kepuasan konsumen, artinya semakin tinggi kualitas pelayanan maka semakin tinggi tingkat kepuasan dan loyalitas konsumen, begitu pula pada variabel kualitas produk yang berbanding lurus atau positif terhadap tingkat kepuasan konsumen, artinya semakin tinggi kualitas produk maka semakin tinggi tingkat kepuasan konsumen.

Berdasarkan hasil uji $t$ menunjukkan bahwa kedua variabel bebas yakni, kualitas pelayanan dan kualitas produk memiliki pengaruh secara tersendiri dan signifikan terhadap variabel terikatnya yakni, kepuasan konsumen.

Berdasarkan hasil uji $\mathrm{F}$ menunjukkan bahwa kedua variabel bebas yakni, kualitas pelayanan dan kualitas produk secara bersamasama berpengaruh atau mempengaruhi variabel terikatnya yakni, kepuasan konsumen.

Berdasarkan uji $\mathrm{R}^{2}$ menunjukkan bahwa kedua variabel bebas yakni, kualitas pelayanan dan kualitas produk secara bersama-sama memiliki sumbangan pengaruh sebesar $81,1 \%$ terhadap variabel terikatnya yakni, kepuasan konsumen.

KFC dapat meningkatkan lagi kualitas pelayanan baik dari keramahan karyawan dalam melayani konsumen, kecepatan karyawan dalam melayani konsumen, hingga kebersihan fisik restoran. Karena, berdasarkan hasil penelitian kami, kualitas pelayanan masih lebih rendah daripada kualitas produk.

\section{REFERENSI}

Assauri, Sofjan. 2015. Manajemen Pemasaran. Jakarta : Rajawali Pers. Sangadji, E.M dan Sopiah 2015. Prilaku Konsumen : Pendekatan Praktis Disertai: Himpunan Jurnal Penelitian. Yogyakarta : Andi

Familiar, K., \& Ida Maftukhah. (2015). Pengaruh Kualitas Produk dan Kualitas Pelayanan terhadap Loyalitas Pelanggan Melalui Kepuasan Pelanggan. Management Analysis Journal, 4(4), 348-354 
Fatihaha Dinda Zahra. (2021). Pengaruh Kualitas Pelayanan dan Kualitas Produk Terhadap Kepuasan Konsumen Pada KFC Home Centa Medan. Skripsi Program Studi Ilmu Administrasi Bisnis Fakultas Ilmu Sosial dan Ilmu Politik Universitas Sumatera Utara MEDAN

Hartanto, A. (2019). Pengaruh Kualitas Produk, Kualitas Layanan dan Lingkungan Fisik Terhadap Loyalitas Pelanggan Melalui Kepuasan Pelanggan Sebagai Variabel Mediasi di De Mandailing Cafe Surabaya. Agora, 7(1), 2019.

Kastawan mandala, and Muhammad Ryan Fauzi. 2019. "Purposive Sampling." Pengaruh Kualitas Pelayanan Dan Inovasi Produk Terhadap Kepuasan Untuk Meningkatkan Loyalitas Pelanggan 8 (11): 6741-61.

Kolter,P.,\& Keller, K.L. (2009). Manajemen pemasaran (12th Ed; PT Indeks, Ed.). Jakarta : PT Mancana Jaya Cemerlang

Krisdianti, Dika Lambang, and Fakultas Ilmu Administrasi. 2019. "Pengaruh Kualitas Pelayanan Terhadap Kepuasan Konsumen Pada Restoran Pizza Hut Malang Town Square" 70 (1): 36-44. Malik Ibrahim Siti Marijam Thawil. 2019. "Pengaruh Kualitas Produk Terhadap Kepuasan Pelanggan" 4 (1): 175-82.

Lupiyoadi R, Hamdani A. 2016. Manajemen Pemasaran Jasa. Jakarta (ID): Salemba Empat.

Mutiara, dkk 2021. Pengaruh kualitas pelayanan dan kualitas produk terhadap Kepuasan Konsumen Pada Restoran KFC Lampung, Jurnal Ilmu Manajemen Sabura, Vol 7 No 12021 E-ISSN 26217937 P-ISSN 2774-7026

Malik Ibrahim Siti Marijam Thawil. 2019. "Pengaruh Kualitas Produk Terhadap Kepuasan Pelanggan" 4 (1): 175-82
Purnomo Edwin Setyo. 2017. "Pengaruh Kualitas Produk Dan Harga Terhadap Kepuasan Konsumen "Best Autoworks"

Tjiptono, Fandy. 2012. Service, Quality \& Satisfaction (Yogyakarta: CV Andi Offset)

Tjiptono \& Chandra, G. 2011. Pemasaran Strategik. Edisi Kudua. Yogyakarta: ANDI. Tjiptono, Fandy dan G

Weenas, Jackson R.S. 2013. Kualitas Produk, Harga, Promosi, dan Kualitas Pelayanan Pengaruhnya Terhadap Keputusan Pembelian Spring Bed Comforta. Jurnal EMBA vol.1 no.4 Desember 2013

Woro, M., \& Naili, F. (2013). Pengaruh nilai pelanggan dan kualitas layanan terhadap loyalitas pelanggan, melalui kepuasan pelanggan pada pelanggan bus efisiensi (Studi PO Efisiensi Jurusan YogyakartaCilacap). Jurnal Administrasi Bisnis, 2(1). 